ROCZNIKI HUMANISTYCZNE

Tom LXVIII, zeszyt $6-2020$

DOI: http://dx.doi.org/10.18290/rh20686-5

JOLANTA KLIMEK-GRĄDZKA

\title{
GODZINKI MOSKALOFILSKIE TELESFORA CHEŁCHOWSKIEGO - UWAGI O STRUKTURZE I STYLU
}

\begin{abstract}
„Niekwestionowanym bogactwem naszej wiary, ale i naszej kultury, jest pobożność ludowa. [...] Wyróżnikiem polskiej pobożności ludowej jest jej maryjność” - ze słusznością tej tezy Andrzeja Potockiego („Katecheza maryjna w spotkaniu z tradycjami polskiej pobożności ludowej” 145) dyskutować nie sposób ${ }^{1}$. Jednym z przejawów rozwijającego się od średniowiecza kultu maryjnego jest wielość form modlitewnych Maryi poświęconych lub do Niej skierowanych, by wymienić litanie, pieśni, koronki czy wreszcie godzinki. Te ostatnie, choć nie mają rodowodu polskiego, jak pokazuje m.in. ks. Józef J. Kopeć („Małe oficja i godzinki staropolskie”), z biegiem czasu rozszerzone zostały nie tylko na inne niż niepokalane poczęcie aspekty dogmatu maryjnego, ale także na innych świętych chrześcijańskich. Do dziś jednak za kanoniczną (w słownikowym, nie genologicznym tego słowa rozumieniu) postać godzinek uchodzą Godzinki o Niepokalanym Poczęciu NMP one też stały się kanwą przywołanego w tytule opracowania tekstu.

O autorze tytułowych Godzinek moskalofilskich wiadomo bardzo niewiele. Telesfor Chełchowski to zmarły w połowie 1917 r. w San Antonio działacz polityczny i społeczny, redaktor naczelny socjalistycznego pisma polonijnego Bicz Boży (Stownik pseudonimów 4: 85). Pod wiele mówiącym pseudonimem „Szczypawka” publikował na łamach swego pisma, później
\end{abstract}

Dr hab. JolAnTA KLIMEK-GRĄDZKA, prof. KUL - profesor nadzwyczajny w Katedrze Języka Polskiego Instytutu Językoznawstwa Katolickiego Uniwersytetu Lubelskiego Jana Pawła II; adres do korespondencji: Katolicki Uniwersytet Lubelski Jana Pawła II, Al. Racławickie 14, 20-950 Lublin; e-mail: jolanta.klimek@kul.pl; ORCID: https://orcid.org/0000-0002-6289-5634.

${ }^{1}$ Nie sposób też przywołać w tym miejscu pełnej literatury przedmiotu dotyczącej pobożności maryjnej czy modlitewnych przejawów kultu maryjnego. Z lingwistycznych opracowań godzinek dla porządku należy przywołać: Breza, Karpluk „Ze studiów nad językiem”, taż, „W Maryjnym skarbcu”, Henryki Sędziak „Cechy językowe Godzinek o Niepokalanym Poczęciu Najświętszej Marii Panny". 
część także w postaci zwartej, zaangażowane politycznie artykuły pod wiele mówiącymi tytułami, m.in.: Kolendy Robotnicze (Chicago 1912), Baczność! Jenerat tabaka ma głos (Chicago 1913), Co Jenerat tabaka mówi o wojnie, czyli Najlepszy plan zbawienia Polski, opracowany przez sztab gieneralny wojska polsko-amerykańskiego (Chicago 1913), Humorystyczne listy z terenu wojny (Chicago 1915), Godzinki moskalofilskie (Chicago 1917), Gorzkie żale moskalofilskie (1917).

Będące przedmiotem oglądu w niniejszym opracowaniu Godzinki moskalofilskie z podtytułem 300 dni taski carskiej za każdorazowe odmówienie tych godzinek $z$ pokora i skruszonym sercem i w warstwie treściowej, i ideologicznej realizują zalecenia przyjętego na zjeździe założycielskim w Pittsburghu w 1912 r. statutu Komitetu Obrony Narodowej:

\begin{abstract}
Oddaleni tysiące mil od Ojczyzny, nie mogąc brać czynnego udziału w polityce narodowej poddajemy się pod bezwzględną dyktaturę Zjednoczonych Niepodległościowych Partii w Polsce, reprezentowanych przez swych delegatów na zjeździe w Zakopanem jesienią roku 1912 i tworzących obecnie Polski Skarb Wojskowy. Stosownie do orientacji politycznej dokonanej już w kraju przez powyższe partie postanawiamy popierać wszelkimi środkami ruch powstańczy przeciw Rosji, największemu wrogowi Polski, przedstawicielce ucisku, wynaradawiania, barbarzyństwa i ciemnoty i odwiecznemu żandarmowi absolutyzmu w Europie (za: Szczepański 52; wyróż. aut. JKG).
\end{abstract}

Telesfor Chełchowski jako aktywista tzw. czwartej dzielnicy tworzył teksty wpisujące się w bieżącą problematykę i odpowiadające poetyce sporów politycznych przełomu XIX i XX wieku. Jednocześnie, sięgając po dobrze znane Polakom gatunki wypowiedzi (list, kolęda, godzinki, gorzkie żale), wpisywał się w polską tradycję i korzystał $\mathrm{z}$ utrwalonych wzorców gatunkowych i konotacji, jakie z sobą niosą. Łatwo to dostrzec już na poziomie tytułów wymienionych wyżej publikacji.

W niniejszym szkicu chcę przyjrzeć się Godzinkom moskalofilskim tytułem nawiązującym do Godzinek o Niepokalanym Poczęciu Najświętszej Maryi Panny, o których Andrzej Sulikowski pisze, że „stały się w czasie rozbiorów szczególnym klejnotem języka i wiary" (256). Interesować mnie będzie ukształtowanie strukturalne i stylistyczne utworu „Szczypawki”, a także odzwierciedlający się poprzez sytuację pragmatyczną i cechy gatunkowe związek z wzorcem modlitewnym.

\footnotetext{
${ }^{2}$ Andrzej Chwalba pisze, że to zbiór 10 kolęd autorstwa robotników z ugrupowań socjalistycznych (33).
} 


\section{STRUKTURA TEKSTU}

Na Godzinki moskalofilskie T. Chełchowskiego składają się kolejno: jutrznia, pryma, tercja, seksta, nona, nieszpory i kompleta, które zawierają zaczęcie, hymn, wersety i responsoria, modlitwę. Łatwo więc dostrzec, że tekst ma budowę odpowiadającą najlepiej w polskiej tradycji zakorzenionemu siedmioczęściowemu nabożeństwu wotywnemu, małym godzinkom (Kopeć 43). Odstępstwem od wzorca kanonicznego jest zredukowana forma ofiarowania (Polecenie Godzinek), któremu towarzyszy jedynie antyfona, brakuje natomiast modlitwy. Naruszeniem wzorca jest także modyfikowane w każdej z godzin zaczęcie, co koreluje $\mathrm{z}$ treścią i odbiorcą hymnu.

Części godzinek wyróżniane są konsekwentnie tytułem o składni na+ nazwa godziny liturgicznej, np.: Na jutrznię, Na nonę, Na sextę. W każdej z nich tytułowany jest także, inaczej niż w modlitewnym wzorcu, hymn. Inaczej też niż w Godzinkach o Niepokalanym Poczęciu NMP kolejne hymny są poświęcone różnym postaciom, mamy więc m.in. Hymn do cara, Hymn do kniazia Mikołaja Mikołajewicza czy Hymn do Suworowa.

Chełchowski-Szczypawka nie ogranicza się do naśladownictwa zewnętrznej struktury liturgicznych Godzinek. Idzie dalej, dlatego można zastanawiać się, czy Godzinki moskalofilskie to nie wielowymiarowa trawestacja kanonicznego wzorca - przy trawestacji rozumianej za Ryszardem Nyczem jako

transformacja obiektu w rezultacie użycia niestosownego stylistycznego wzorca do artykulacji nowego tematu, bądź też zachowanie fabularno-kompozycyjnego układu wzorca w celowo ,nieodpowiednim” stylistycznie jego wysłowieniu. Cechy wyróżniające te trzy formy - parodię, burleskę oraz trawestację - częściowo się na siebie nakładają i krzyżują (172).

Pierwszym $\mathrm{z}$ argumentów przemawiających za taką interpretacją tekstu „Szczypawki” jest konsekwentnie stosowany w wezwaniach i hymnach wzorzec metryczny, tj. trzynastozgłoskowiec, zgodnie też z kanonem realizowany jako układ $7+6$ rymowany parzyście, choć dystych rozbity jest graficznie na dwa wersy, np.:

Zacznijcie wargi nasze / chwalić batkę-cara,

Zacznijcie sławić dziegieć, / Niech weń rośnie wiara. 
Przybądź nam miłościwy / Carze ku pomocy,

A wyrwij nas z koniowców3 / i socjałów mocy. [GM 3] ${ }^{4}$

Jak pokazuje powyższy cytat, analizowany tekst przejmuje z wzorca także postać wezwania i zachęty:

Godzinki NMP:

Zacznijcie wargi nasze, chwalić Pannę świętą,

Zacznijcie opowiadać cześć jej niepojętą.

Godzinki moskalofilskie:

Zacznijcie wargi nasze / Chwalić batkę-cara,

Zacznijcie sławić dziegieć, / Niech weń rośnie wiara. [GM 3],

oraz apostrofę drugiego dystychu:

Godzinki NMP:

Przybądź nam milościwa pani, ku pomocy,

A wyrwij nas z potężnych nieprzyjaciół mocy.

Godzinki moskalofilskie:

Przybądź nam miłościwy / Carze ku pomocy,

A wyrwij nas z koniowców / I socjałów mocy. [GM 3]

Dalsza część rozpoczęcia u Chełchowskiego jest przekształceniem klasycznej doksologii chrześcijańskiej

Chwała Ojcu i Synowi Jego Przedwiecznemu,

I równemu Im w Bóstwie Duchowi Świętemu.

Jak była na początku i zawsze i ninie,

Niech Bóg w Trójcy Jedyny na wiek wieków słynie

w formułę głoszącą chwałę cara i bohatera hymnu następującego po wezwaniu, co stanowi odstępstwo od wzorca maryjnego, w którym rozpoczęcia kolejnych godzin są identyczne, np.:

${ }^{3}$ Od KON - Komitet Obrony Narodowej działający w USA od 1912 do 1921 r., mający za zadanie skonsolidowanie Polonii amerykańskiej, opowiadał się przeciw Rosji jako patronce polskiej niepodległości, popierał dążenia J. Piłsudskiego. Prasowym organem KON-u był tygodnik „Wici” wydawany w Chicago (Ustawy Komitetu obrony narodowej...).

${ }^{4} \mathrm{GM}$ - Godzinki moskalofilskie. Wszystkie cytaty za wydaniem drugim Chicago 1917, cyframi w nawiasie kwadratowym oznaczam numer strony. Zachowuję pisownię oryginału, a wszystkie wyróżnienia w cytatach pochodzą ode mnie. 


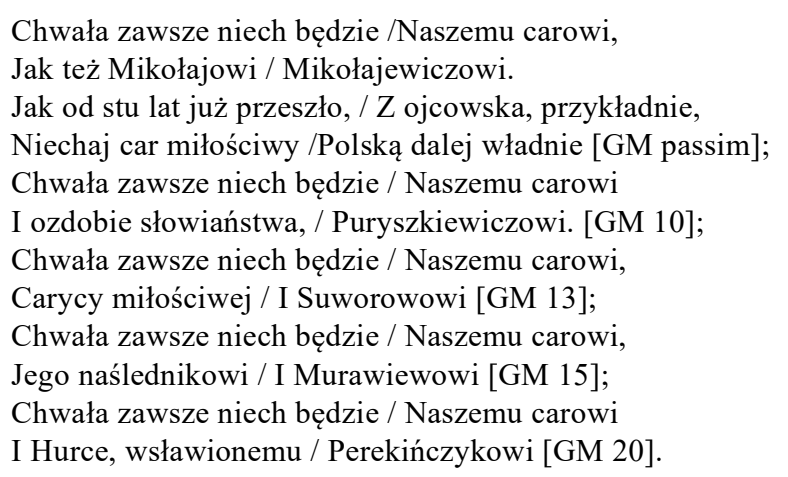

Bezpośrednio z religijnym pierwowzorem łączą się Godzinki moskalofilskie również za sprawą apostroficznego otwarcia hymnów: Zawitaj Gosudarze; Witaj arko przymierza; Zawitaj, Suworowie; Zawitaj Murawiewie, Wieszatielu mity; Zawitaj Apuchtinie.

Rodowód modlitewny mają także formuły kończące zaczęcia i hymny ${ }^{5}$ :

Niechaj car miłościwy / Polską dalej władnie [passim];

Niech ci za twoje trudy / Jasność wieczna świeci [GM 18];

Niech cześć twoja wśród Słowian / Na wiek wieków słynie [GM 16].

Ostatnim strukturalnym elementem przejętym $\mathrm{z}$ wzorca i poddanym trawestacji są wersety i responsoria następujące po hymnie i/lub modlitwie, np.:

Godzinki NMP:

K. Pani, wysłuchaj modlitwy nasze,

W. A wołanie nasze niech do Ciebie przyjdzie.

K. Błogosławmy Panu,

W. Bogu chwała.

K. A dusze wiernych zmarłych przez miłosierdzie Boże niech odpoczywają w pokoju.

W. Amen.

Godzinki moskalofilskie:

V. Carze wysłuchaj modlitwy nasze.

R. A wołanie nasze niech do ciebie przyjdzie.

V. Błogosławmy cara.

R. Carom chwala.

V. A dusze wierne carowi przez milosierdzie carskie niech piją zawsze "oczyszczoną" [GM 6].

\footnotetext{
${ }^{5}$ Tu nie bezwyjątkowo - czasem życzenie znajduje się w pierwszej części hymnu.
} 


\section{STYL TEKSTU}

Najliczniejszą grupę nawiązań do ukształtowanego w połowie XVIII wieku tekstu Godzinek o Niepokalanym Poczęciu Najświętszej Maryi Panny (odnoszę się tu do ustaleń Marii Karpluk, „W Maryjnym skarbcu”) stanowią nawiązania stylistyczne i semantyczne. Sytuacja pragmatyczna Godzinek moskalofilskich Chełchowskiego wymagała zmiany adresata modlitwy, stąd też zamiast wezwań do Maryi Panny i Boga pojawiają się wezwania do cara i kolejnych bohaterów hymnów ${ }^{6}$ :

Mikołaj II Romanow (1868-1918, ostatni car Rosji) - Car, batko-car, car-batiuszka, Gosudar, władca wszechstowiański; car nad cary; filar niebiański, peten łaski; samodzierżca wszechsłowiański;

Mikołaj Mikołajewicz (1856-1929, wnuk cara Mikołaja I, w odezwie z 4 sierpnia 1914 r. zawarł obietnicę zjednoczenia po zakończeniu wojny ziem polskich z trzech zaborów pod berłem cara i nadania im autonomii) kniaź mądry; gwiazda z nad Wotgi; słowiańszczyzny chwała; wielkiej Rosji Stońce [...] jedyne; Dobroci obraz; kniaź najdobrotliwszy; chluba i pociecha całej stowiańszczyzny;

Wladimir Puryszkiewicz (1870-1920, zwolennik panslawizmu) - ozdoba stowiaństwa; arka przymierza; brat-stowianin; mistrz nad mistrze; Gieroj od pogromów; krzak dziegciowy carosławnym ogniem gorejacy; kwiat kultury stowiańskiej; najukochańszy mistrz wszechsłowiański; brat ukochany;

Aleksander Suworow (1729-1800, od 1768 r. walczył z konfederatami barskimi; wsławił się tłumieniem insurekcji kościuszkowskiej, rzezią Pragi i zdobyciem Warszawy w 1794) - gienerat wielki; prorok wszechwidzacy; Przezacny brat słowiański, najukochańszy rzeźnik Pragi;

Michal Murawiew (1796-1866, po wybuchu powstania styczniowego mianowany generał-gubernatorem Litwy, z jego rozkazu powieszono 127 osób w guberniach litewskich i 50 w guberni augustowskiej, głównie powstańców) - Wieszatiet mily; źródło Miłości gorące; czcigodny; nieprzebrane źródto stowiańskiego patriotyzmu;

Aleksander Apuchtin (1822-1903, rosyjski kurator warszawskiego okręgu szkolnego, twórca zrusyfikowanego, policyjnego, systemu szkolnictwa w Królestwie Polskim, opartego na reformie programów szkolnych i donosach) - zorza zarania; reformator Wielki Prywiślanja; Najukochańszy batiuszka;

Josif Hurko - (1828-1901, rosyjski feldmarszałek, który w latach 18831894 był generał-gubernatorem warszawskim i dowódcą Warszawskiego

\footnotetext{
${ }^{6}$ Sprowadzam je do postaci mianownika, zachowuję ortografię oryginału.
} 
Okręgu Wojskowego. Zasłynął jako prześladowca unitów i zaciekły zwolennik rusyfikacji, wyrugował język polski ze szkół i urzędów, zaostrzył cenzurę) - wstawiony Perekińczyk; przywiślańców zacny przewodnik; mą̇ szlachetny; cny pierekińczyk; Patron najdroższy; brat nasz.

Stosowane tu nominacje i towarzyszące im deskrypcje stanowią łatwo rozpoznawalną adaptację/parafrazę obrazowania Boga, Jezusa i Maryi. Proweniencję biblijną czy modlitewną mają hebraizmy wyrażające superlatyw: car nad cary, mistrz nad mistrze, a także stanowiące centrum metafory leksemy gwiazda, stońce, źródto, zorza.

Relacja pomiędzy podmiotem a adresatem hymnów także wykazuje proweniencję modlitewną: moskalofile zwracają się z prośbą do cara bezpośrednio lub za pośrednictwem innych adresatów. Tym samym ci ostatni zajmują modlitewną pozycję Maryi, np.:

\footnotetext{
Błagamy ciebie nie opuszczaj nas, a wstaw się za nami do twojego najmiłościwszego stryja, najjaśniejszego cara wszechsłowiańskiego, Mikołaja drugiego, aby raczył zmiłować się nad nami niegodnymi i niedopuścić do takiej strasznej rzeczy, jak wolność i niepodległość Przywiślanja, po buntowniczemu „Polską” zwanego. [GM 9];

zmiluj się nad nami i racz przybyć tu do Ameryki organizować pogromy na buntowniczych koniowców i socjalistów [GM 12];

wstaw się za nami do pana boga słowiańskiego, aby nas raczył czymprędzej pod berłem najmiłościwszego cara i samodzierżcy wszechsłowiańskiego [GM 14-15].
}

W Godzinkach moskalofilskich zwraca też uwagę antylogia jako wyrazisty model epitetu, np.: cny pierekińczyk, najukochańszy rzeźnik Pragi, Wieszatiel mity, oparty na jednolitym schemacie: waloryzujący przymiotnik + deprecjonujący rzeczownik osobowy. Dodam, że także w innych utworach Chełchowskiego występują takie antylogie, co pozwala w nich widzieć cechę idiostylową „Szczypawki”.

O ile obrazowanie i wartościowanie cara jako władcy, ojca i opiekuna bazuje na obrazie Boga Ojca, np.: miłościwy, obdarzony boskim uczuciem litości, najmiłościwszy, a jego relacja z Polską i Polakami jest paralelna do relacji Boga Ojca z ludźmi:

Z ojcowska, przykładnie, [...] / Polską dalej władnie [GM 3];

Zawitaj pełen laski, / Uczucia boskiego, / Wybaw nas jak najprędzej / Z ucisku polskiego [GM 4];

Wejrzyj na nas laskawym okiem milosierdzia swego [GM 5], 
o tyle zakres władzy cara (i pozostałych bohaterów hymnicznych) jest węższy: panowanie Boga i orędownictwo Maryi rozciąga się na cały świat, natomiast cara na Słowiańszczyznę ${ }^{7}$, co nie przeszkadza Chełchowskiemu tworzyć przydawki z przedrostkiem wszech-. Trzeba tu zauważyć, że wysoką frekwencję mają wszelkie formacje superlatywne - zarówno te odnoszące się do adresatów wezwań, jak i przeciwników politycznych podmiotu. Obraz tych ostatnich kreślony jest na podobieństwo modlitewnego obrazu szatana i grzeszników i wykorzystuje leksykę i topikę z pola leksykalnego BUNT, UCISK, ZDRADA, m.in.: buntowniczych Legjonów Polskich [GM 5], od ucisku miateżników polskich, gnębiących naród twój wierny [GM 5], niewiernych żydów [GM 12].

Wśród intencji kierowanych do adresatów hymnów wybrzmiewają korelujące z kontekstem politycznym prośby o zaniechanie działań bądź podjęcie działań przeciwskutecznych, np.:

niedopuść, aby za sprawą tych buntowniczych Legjonów Polskich i ich wodza, Piłsudskiego, — Polska odzyskała niepodległość! [GM 5].

Korelują z nimi obietnice składane przez modlących się, np.:

przyrzekamy ci jak najsolenniej, że w połączonej pod berłem twoim Polsce wytropimy wszystkich socjalistów i niepodległościowców - i tobie ich w ręce oddamy [GM 6].

Jak w modlitewnym wzorze pojawiają się informacje z życia Maryi i jej roli historiozbawczej, tak w Godzinkach moskalofilskich w apostrofach do Rosjan przywołuje się wydarzenia z ich życia i działalności antypolskiej, np.: o Suworowie - wyrżnateś z litości / Cała ludność Pragi [GM 14]; o Murawiewie -

\footnotetext{
Tyś postawił w swe rządy

Szubienic tysiące.

Wieszałeś miatieżników

Polskich, co niemiara,

Bo śmieli rękę podnieść

Na batiuszkę-cara.

Słałeś na stryk każdego,

O mężu przebiegły,

Co choć w myśli zażądał
}

\footnotetext{
${ }^{7}$ Zwłaszcza w tym kontekście uderza wykorzystanie przez Chełchowskiego niemal na prawach cytatu Ewangelii wg św. Jana: ,niech będzie car jedyny i jedna owczarnia” [GM 11].
} 


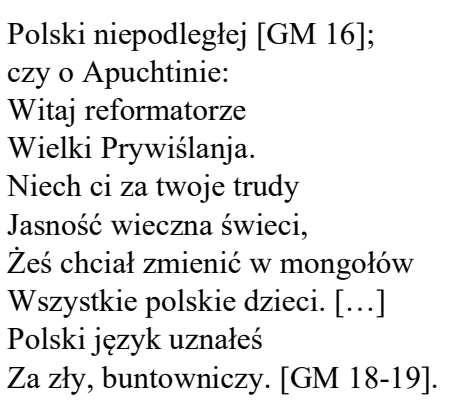

Nadawca ujawniający się w modlitwie konsekwentnie występuje w 1 os. 1. mn. my. Wypowiada się jako przedstawiciel stronnictw rusofilskich dobrze już zakorzenionych $\mathrm{w}$ historii Polski: obiecateś nam spetnienie marzeń naszych targowiczan-ojców [GM 9], My, prawi potomkowie / Starej Targowicy [GM 7]; my, wierni wyznawcy cara-batiuszki [GM 13].

Nadawca w relacji do adresatów modlitw przyjmuje postawę pokorną, jawi się jako słaby, wymagający pomocy, co znajduje odzwierciedlenie tak w autoprezentacji za pomocą przydawek, jak i czasownikach mówienia identyfikujących akty mowy, m.in.: Blagamy ciebie nie opuszczaj nas [GM 9]; aby raczyt zmiłować się nad nami niegodnymi [GM 9]; blagamy cię, o gosudarze najmilszy, wystuchaj próśb naszych pokornych [GM 6]. Niesymetryczną relację nadawczo-odbiorczą oddają także leksemy nazywające szacunek do obiektu modlitewnego: cześć, czcić, chwalić, np.:

\author{
Czczą cię niewolnicy [GM 7]; \\ Cześć ci za to, że żądasz \\ Aby wszystkie Lachy, \\ Smarowali się dziegciem, \\ Nosili "rubachy". \\ Cześć ci za to, że wszystkich, \\ Słowiańskich, tunguskich, \\ Inorodców - zamienić \\ Chcesz w istinno-ruskich. [GM 11]; \\ Ciebie ze czcią wspomina \\ Przywiślaniec wszelki. [GM 13]; \\ Pochwalon bądź więc mężu, \\ Zawsze, tak jak nynie, \\ Niech cześć twoja wśród słowian \\ $\mathrm{Na}$ wiek wieków słynie [GM 16]; \\ Sława ci za te czyny, \\ Pamięć twa jest czczoną, \\ Obyś za to miał zawsze \\ W raju - "oczyszczoną" [GM 22].
}


W tę konwencję wpisują się również wspomniane już wyżej superlatywy w podnoszonym tu kontekście wpisujące się w obraz nadawcy wartościującego swój przekaz: przyrzekamy ci jak najsolenniej [GM 6], oraz wartościujące odbiorców czy bohaterów modlitw: najmiłościwszego cara [GM 15], najukochańszy rzeźniku Pragi [GM 14], najukochańszy nasz mistrzu wszechstowiański, Puryszkiewiczu [GM 12], najmiłościwszego stryja, najjaśniejszego cara wszechstowiańskiego, Mikołaja drugiego [GM 9], najjaśniejszego cara [GM 9], najdobrotliwszy kniaziu [GM 9], Patronie nasz najdroższy [GM 21].

Bezpośrednio z sakralnym kontekstem powiązane są też wezwania do adresatów modlitw i werbalizowane w nich imperatywy, m.in.: o bracie ukochany, zmiluj się nad nami i racz przybyć tu do Ameryki organizować pogromy na buntowniczych koniowców i socjalistów [GM 12]; wstaw się za nami grzesznymi do stwórcy Wszechstowiańskiego [GM 20].

Jak stwierdził Ryszard Nycz, wśród funkcji parodii widzieć można „,[narzędzie] ośmieszającej demaskacji zjawisk pozaliterackich i pozajęzykowych” (166). Zadanie to w Godzinkach moskalofilskich „Szczypawki” poza wymienionymi dotychczas zjawiskami realizuje także dysonans stylistyczny rozpatrywany bez odniesienia do modlitewnego wzorca. Wywołują go nie tylko wynikające wprost $\mathrm{z}$ trawestacji powiązania kontekstów sakralnych ze świeckimi (carskimi), ale także wplecione w nie wtręty z języka potocznego, np.:

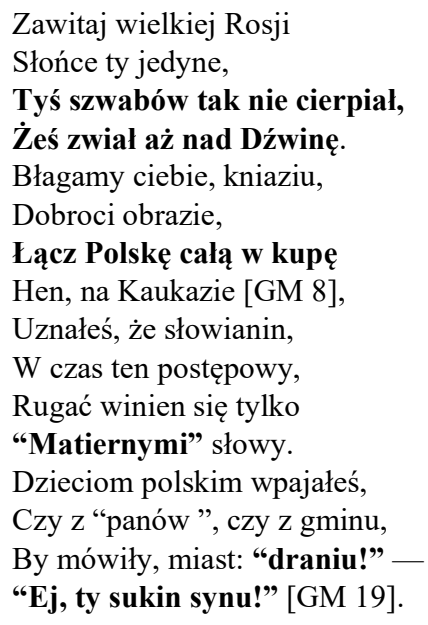

„Trawestacje literatury religijnej byłyby więc zjawiskiem symptomatycznym dla czasów rozprzężenia, upadku autorytetów politycznych i ogólnego zamętu" pisze M. Pieczyński („Pokusy czasu oblężenia. O trawestacjach literatury religijnej w staropolskim piśmiennictwie politycznym" 312) i pozwala włączyć tekst 
T. Chełchowskiego w polską tradycję literacką. Spory stronnictw o powojenną wizję odrodzonej Polski, kakofonia propozycji ideologicznych, dezinformacja panująca po obu stronach Atlantyku ${ }^{8}$ i chęć przedarcia się do świadomości Polonii z poglądami socjalistycznymi staje się powodem, dla którego Chełchowski sięga po tekst wyjątkowy dla Polaków, tekst o którym Maria Karpluk pisze, że „zajmuje miejsce niepoślednie” wśród utworów wpisujących się w kult maryjny („W Maryjnym skarbcu” 18). Tym, co pozornie odróżnia Godzinki od pozostałych tekstów „Szczypawki”, zwłaszcza Humorystycznych listów z podróży, jest eksplicytnie wyrażona krytyka „koniowców i socjałów”, przed którymi chronić ma car, adresat modlitwy. Dopiero lektura tekstu ujawnia, w kogo wymierzone jest faktyczne ostrze satyry: w rusofilów, w carze Rosji upatrujących nadziei na wolną Polskę. Tym samym Godzinki moskalofilskie wpisują się w wielowiekową tradycję zaangażowanych społecznie trawestacji tekstów modlitewnych.

Aleksander Brückner twierdził, że ,[j]]ad zarazy rusofilskiej szerzył się dzięki prasie krajowej, co spętana przez cenzurę wojskową, mogła tylko głosy rusofilskie wygłaszać" (44). Prasa emigracyjna wolna była od tych ograniczeń - Chełchowski tak na łamach swego Bicza Bożego, jak i w tekstach zwartych, werbalizuje konsekwencje odrodzenia się Polski pod berłem moskiewskim:

Ciebie błagamy, batko,

Serdecznie i szczerze:

Złącz Polskę pod swe berło

$\mathrm{W}$ języku i wierze.

Zlącz Polskę pod nahajkę

Jak najprędzej całą

By plemię polskie dłużej

W szkołach nie dziczało.

Wprowadź do nas słowiańskiej

Kultury ślad znany:

Szubienice i tiurmy,

Sybir i ochrany [GM 4];

w zamian za twoje dobrodziejstwa, przyrzekamy ci jak najsolenniej, że w połączonej pod berłem twoim Polsce - wytropimy wszystkich socjalistów i niepodległościowców - i tobie ich w ręce oddamy, abyś po ojcowsku na szubienicach ich powywieszał [GM 6].

Konfrontacja kolokacji w obrazowaniu cara i bohaterów/adresatów kolejnych godzin z kolokacjami i określeniami Maryi wydobytymi z Godzinek przez Marię Karpluk („Ze studiów nad językiem”) i Edwarda Brezę, ujawnia

\footnotetext{
${ }^{8} \mathrm{Z}$ tym m.in. mierzy się Chełchowski w Humorystycznych listach z podróży.
} 
zbieżności w planie strukturalnym (składniowym) i stylistycznym. To zaś w połączeniu z omówioną zależnością kompozycyjną Godzinek moskalofilskich od Godzinek o Niepokalanym Poczęciu NMP pozwala widzieć w tych pierwszych okaz gatunku w rozumieniu zaproponowanym przez Marię Wojtak, tj. „twórcze odniesieni[e] do reguł wzorca, na tyle jednak przejrzyste, by nie naruszały tożsamości gatunku" (65).

Jak pokazały badania stylistyczno-językowego ukształtowania zbiorów gawęd i listów, a także Gorzkich żali moskalofiskich ${ }^{9}$, Chełchowski jest mistrzem w wykorzystaniu i przetworzeniu dobrze rozpoznawalnych w kulturze polskiej gatunków do walki politycznej. Wolność wypowiedzi, zagwarantowana tak przez prawo amerykańskie, jak i kostium satyry, w który ubiera bliski Polakom tekst religijny, a także potoczny, nasycony parodystycznie wtrętami rosyjskimi, język polski zrozumiały dla Polonii ${ }^{10}$, stają się w wykonaniu „Szczypawki” narzędziami walki o socjalistyczną niepodległą Polskę. Badacze dawniejszych tekstów parodiujących czy trawestujących utwory religijne są zgodni, że obca ich twórcom była motywacja antyreligijna (por. Choroszy). Paweł Pietrzyk twierdzi, że „to nie utwór pierwotny jest w jakikolwiek sposób ośmieszany, wręcz przeciwnie - z jego pomocą (właśnie poprzez parodię) dokonuje się negatywna ocena rzeczywistości, w której żyje autor. Zauważalny dysonans struktury tekstu i jego zawartości ma być widomym znakiem krytycznej i nonkonformistycznej postawy wobec świata" (60). Maciej Pieczyński, analizując barokowe teksty, stwierdza, że „trawestacj[e] modlitw [...] nie miały [...] podważać autorytetu religii ani służyć anarchicznemu burzeniu porządku społecznego. Już prędzej - utwierdzeniu i propagowaniu takiej jego wersji, która byłaby zgodna $\mathrm{z}$ materialnym i światopoglądowym interesem autora" (313). Analogiczną motywację moim zdaniem można przypisać T. Chełchowskiemu: Godzinki moskalofilskie nie są kpiną z dobrze rozpoznawanego przez Polaków i nieodłącznego kulturze religijnej maryjnego gatunku modlitewnego (por. Kopeć 55), ale (kolejnym) narzędziem w walce politycznej.

\footnotetext{
${ }^{9}$ Artykuł w druku.

${ }^{10}$ Teksty Chełchowskiego nigdy nie ukazały się w Polsce, dlatego emigrantów uznaję za jedynych odbiorców jego twórczości.
} 


\section{ŹRÓDŁO}

„Szczypawka” [Telesfor Chełchowski]. Godzinki moskalofilskie, wyd. 2, 1917. polona.pl/item/ godzinki-moskalofilskie-300-dni-laski-carskiej-za-kazdorazowe-odmowienie-tych-godzinek. Dostęp 10.01.2019.

\section{LITERATURA}

Breza, Edward. „Epitety i wyrażenia dotyczące Matki Bożej z Godzinek o Niepokalanym Poczęciu NMPanny". Językoznawstwo: współczesne badania, problemy i analizy językoznawcze, nr 9, 2015, ss. 13-29.

Brückner, Aleksander. Stowianie a wojna. Uwagi na czasie. Nakładem Centralnego Biura Wydawnictw N.K.N, 1918.

Choroszy, Jan A. „Między teologią a antropologią słowa. O użytkach płynących z Modlitwy Pańskiej”, Napis, XVI, 2010, ss. 43-58.

Chwalba, Andrzej. „Obrzędowość i symbolika religijna w działalności partii socjalistycznych zaboru rosyjskiego (do roku 1905)". Przeglad Historyczny, 74/1, 1983, ss. 29-47.

Jankowski, Edmund, red. Stownik pseudonimów pisarzy polskich, t. 4. Nazwiska, Ossolineum, 1996.

Karpluk, Maria. „W Maryjnym skarbcu polskiego kościoła: Godzinki”. Ruch Biblijny i Liturgicz$n y, 47$, nr 1, 1994, ss. 17-32.

Karpluk, Maria. „Ze studiów nad językiem modlitw staropolskich: Godzinki”. O języku religijnym. Zagadnienia wybrane, red. Maria Karpluk, Jadwiga Sambor, Wydawnictwo KUL, 1988, ss. 103-132.

Kopeć, Jerzy Józef. „Małe oficja i godzinki staropolskie”. Ruch Biblijny i Liturgiczny, 43, nr 1-2, 1990, ss. 42-56.

Nycz, Ryszard. Tekstowy świat. Poststrukturalizm a wiedza o literaturze, t. 2. Wydawnictwo Instytutu Badań Literackich PAN, 1993.

Pieczyński, Maciej. „Pokusy czasu oblężenia. O trawestacjach literatury religijnej w staropolskim piśmiennictwie politycznym". Teksty Drugie, nr 1, 2015, ss. 311-336.

Pietrzyk, Paweł. „Chleba naszego powszedniego zbawileś nas za panowania swego... - o parodiach tekstów religijnych w literaturze XVII i XVIII stulecia”. Napis, seria XIV, 2008, ss. 57-69.

Potocki, Andrzej. „Katecheza maryjna w spotkaniu z tradycjami polskiej pobożności ludowej”. Colloquia Theologica Ottoniana, nr 2, 2018, ss. 145-166.

Sędziak, Henryka. „Cechy językowe Godzinek o Niepokalanym Poczęciu Najświętszej Marii Panny”, Język - Szkoła - Religia, nr 6, 2012, ss. 365-372.

Sulikowski, Andrzej. „Godzinki o Niepokalanym Poczęciu Najświętszej Maryi Panny: glosy, hipotezy, interpretacje". Tematy i Konteksty, nr 6 (11), 2016, ss. 254-301.

Szczepański, Janusz. „Polonia amerykańska w walce o niepodległość Polski”. Niepodległość i Pamięć, 18/3-4 (35-36), 2011, ss. 43-60.

Ustawy Komitetu obrony narodowej na wychodźtwie polskim w Stanach Zjednoczonych Pótnocnej Ameryki. Drukiem Dziennika Ludowego, 1917.

Wojtak, Maria. „Genologiczna analiza tekstu”. Prace Językoznawcze, nr 16/3, 2014, ss. 63-71. 


\title{
GODZINKI MOSKALOFILSKIE TELESFORA CHEŁCHOWSKIEGO - UWAGI O STRUKTURZE I STYLU
}

\begin{abstract}
Streszczenie
Będące przedmiotem analizy Godzinki moskalofilskie. 300 dni laski carskiej za każdorazowe odmówienie tych godzinek z pokora i skruszonym sercem T. Chełchowskiego to tekst odpowiadający poetyce polonijnych sporów politycznych przełomu XIX i XX wieku, a przy tym czerpiący z polskiej tradycji literackiej. Za sprawą nawiązania do modlitewnego wzorca - godzinek, i uwzględniając ich genezę, Godzinki moskalofilskie uznać można za trawestację (w ujęciu Nycza) lub okaz (w ujęciu Wojtak) wzorca modlitewnego. Nawiązanie to przejawia się w siedmioczęściowej budowie (jutrznia, pryma, tercja, seksta, nona, nieszpory i kompleta) z zaczęciem, hymnem, wersetami i responsoriami, modlitwą; konsekwentnie stosowany w wezwaniach i hymnach wzorzec metryczny; apostroficzne otwarcie hymnów; wersety i responsoria następujące po hymnie i/lub modlitwie; nawiązania stylistyczne i semantyczne (wezwania do cara i bohaterów hymnów na wzór apostrof do Boga i Maryi; parafrazy kolokacji biblijnych i modlitewnych). Odstępstwem od wzorca kanonicznego są: zredukowana forma ofiarowania (tylko antyfona), brak modlitwy, modyfikowane w każdej z godzin zaczęcie.
\end{abstract}

Słowa kluczowe: modlitwa; godzinki; genologia; wzorzec gatunkowy; stylistyka.

\section{GODZINKI MOSKALOFILSKIE BY TELESFOR CHEŁCHOWSKI - REMARKS ON STRUCTURE AND STYLE}

\section{Summary}

Subject to analysis in this article is T. Chełchowski's Godzinki moskalofilskie. 300 dni taski carskiej za każdorazowe odmówienie tych godzinek z pokora i skruszonym sercem [Moscophile Hours: 300 Days of Grace for Each Saying of the Hours with Humility and Contrite Heart]. The Hours is a text that fits the general poetics of the political disputes typical of the Polish émigré milieus at the turn of the 20th century. At the same time, the text retains a lot from the Polish literary tradition. Taking into account the fact that the text exploits a prayer as a textual genre (Canonical Hours), and acknowledging the roots of the genre, the Hours can be classified as a travesty (trawestacja in Nycz's approach) or as an idiosyncratic token (okaz in Wojtak's terms) of the prayer genre. The generic linkage is realized by constructing the text of the Hours in seven parts (Matins, Prime, Terce, Sext, Nones, Vespers and Compline) with its introduction, hymn, verses, responsories and prayers; by consecutive use of metre in invocations and hymns; by an apostrophic opening of the hymns; by positioning verses and responsories after hymns or prayers; as well as by stylistic and semantic references (invocations addressed to the Tsar and hymn protagonists, modelled on apostrophes to God and Mary; paraphrases of biblical and prayer collocations). Departures from the canonical text-type include: the reduced form of the final antiphon, lack of prayer and an introduction that is modified per each hour.

Key words: prayer; canonical hours; genre studies; text-type; stylistic. 